\title{
EMBEDDED TOPICALIZATION IN IRISH
}

\author{
HideKI MAKI and DÓNALl P. Ó BAOILL \\ Gifu University and Queen's University Belfast (Prof. Emeritus)
}

This paper investigates the properties of Irish embedded topicalization, and argues (i) that lowering of COMP to INFL does not take place in Irish, (ii) that the Highest Subject Restriction does not apply to resumptive pronouns involved in Irish embedded topicalization, (iii) that the head positions in charge of embedded topicalization are parameterized among languages, (iv) that the difference in the head positions in charge of embedded topicalization lies in the relationship between the COMP and the INFL, and (v) that the ban against adjunction to adjuncts only disallows adjunction to adjuncts by way of internal merge.*

Keywords: embedded topicalization, English, Highest Subject Restriction, Irish, Japanese

\section{Introduction}

Chung and McCloskey (1987) were the first researchers to examine and analyze examples of embedded topicalization in Irish. Their examples are shown in (1). ${ }^{1}$

* This is a revised version of the paper presented at the 30th Conference of the English Linguistic Society of Japan held at Keio University on November 10, 2012. We would like to thank Koji Fujita, Roger Martin, Fumikazu Niinuma, Masao Ochi, and two anonymous EL referees for their valuable comments. Our thanks also go to the following native speakers from the eastern borders of Gweedore Parish in North West Donegal with whom the examples have been checked: Donnchadh Mac Fhionnaile, Seán Mac Giolla Chóill, Bríd Bean Mhic Íomhair, Anna Ní Bhaoill, Máire Nic Giolla Chóill, Pádraig Ó Briain, Pádraig Ó Dúgáin (Éamann), Bríd Bean Uí Ghallchóir, and Méabha Bean Uí Phíopalaigh. All errors are our own. Research by the first author was supported in part by Japan Society for the Promotion of Science Grant \# 25370428 to Gifu University.

1 The abbreviations used in this paper are as follows: $2=$ second person, Acc $=$ accusative, Cond = conditional, $[-$ Fin $]=$ non-finite, Fut $=$ future, Gen $=$ genitive, Impers $=$ impersonal, Nom $=$ nominative, Prog $=$ progressive, $\mathrm{Sg}=$ singular, and Top $=$ topic. 
(1) a. Dúirt sé [duine ar bith a bhí bocht] go dtabharfadh said he person any aL was poor that give.Cond an rialtas deontas dó.

the government a.grant to.him

'He said that the government would give a grant to anyone who was poor.'

b. Dúirt sé [duine ar bith a bhí bocht] gan é said he person any aL was poor that.Neg him a ligean isteach. let.[-Fin] in 'He said not to let anybody in who was poor.' (Chung and McCloskey (1987: 221, 120a, b) slightly edited) The examples in (1) show two remarkable properties of Irish embedded topicalization. First, the topic phrase seems to be in CP SPEC. Second, it does not involve movement, but utilizes the resumption strategy. In this paper, we will investigate the properties of Irish topicalization in more detail, and based on the findings, we claim (i) that lowering of COMP to INFL does not take place in Irish, contrary to McCloskey's (1996) claim, (ii) that the Highest Subject Restriction (HSR) does not apply to resumptive pronouns involved in Irish embedded topicalization, (iii) that both $[-\mathrm{Q}]$ and [+Q] COMPs may bear a [+TOPIC] feature in Irish, and the head positions in charge of embedded topicalization are parameterized among languages, (iv) that the difference in the head positions in charge of embedded topicalization lies in the relationship between the COMP and the INFL, and (v) that the ban against adjunction to adjuncts only disallows adjunction to adjuncts by way of internal merge.

The organization of this paper is as follows. Section 2 reviews the properties of (i) embedded topicalization in English and Japanese and (ii) complementizers in Irish as the background to the subsequent sections. Section 3 provides the embedded topicalization examples in Irish, and Section 4 discusses what they may suggest for the theory of (Irish) syntax. Section 5 addresses one remaining question. Finally, Section 6 concludes this paper.

\section{Background}

In this section, we first review the properties of embedded topicalization in English and Japanese, and then, the properties of complementizers in Irish. First, Maki et al. (1999) report that in American English and Japanese, embedded topicalization is permissible in complement clauses of 
bridge verbs, but impossible in complement clauses of factive verbs or adjunct clauses. The examples in (2) are from American English and those in (3) are from Japanese.

(2) a. John believes that this book, Mary read.

b. John wonders whether this book, Mary read.

c. *John regrets that this book, Mary read.

d. *John believes the rumor that this book, Mary read.

e. *Before this book, Mary read, John had already read it.

(3) a. John-wa [kono hon-wa/-o Mary-ga yonda to $]$

John-Top this book-Top/-Acc Mary-Nom read COMP shinjiteiru.

believe

'John believes that this book, Mary read.'

b. John-wa [kono hon-wa/-o Mary-ga yonda kadooka] John-Top this book-Top/-Acc Mary-Nom read whether shiri tai to omotteiru.

know want COMP think

'John wonders whether this book, Mary read.'

c. John-wa [kono hon-*wa/-o Mary-ga yonda

John-Top this book-Top/-Acc Mary-Nom read no]-o kookaishiteiru.

COMP-Acc regret

'John regrets that this book, Mary read.'

d. John-wa [kono hon-*wa/-o Mary-ga yonda

John-Top this book-Top/-Acc Mary-Nom read

to]-no uwasa-o shinjiteiru.

COMP-Gen rumor-Acc believe

'John believes the rumor that this book, Mary read.'

e. [Kono hon-*wa/-o Mary-ga yomu maeni], John-wa this book-Top/-Acc Mary-Nom read before John-Top sudeni yondeita.

already had read

'Before this book, Mary read, John had already read it.'

Maki et al. (1999) claim that factive verb complements are not L-marked based on the previous studies by Stowell (1981), Grimshaw (1990), and Authier (1992), among others. They state that according to Authier (1992), Watanabe (1993), and in accordance with their own American judgments, embedded topicalization is impossible both in complement clauses of factive verbs and in noun-complement clauses, and argue that it is impossible be- 
cause factive complements are not L-marked, following Authier (1992), and noun-complement clauses are adjuncts, following Stowell (1981) and Grimshaw (1990), among others.

Then, Maki et al. (1999) claim that a topic is licensed in the projection of INFL in overt syntax, and INFL is licensed by adjoining to COMP at LF in English and Japanese. They derived restrictions on embedded topicalization in the two languages from the ban against adjunction to a projection of a non-L-marked head, following Takahashi (1994). We assume their analysis of embedded topicalization in English and Japanese in this paper.

Second, let us review the properties of complementizers in Irish. Irish has three types of complementizers: the $[-\mathrm{Q}]$ marker, the direct relative marker, and the indirect relative marker. The properties of the three COMPs are summarized in (4).

(4) Complementizers in Irish ${ }^{2}$

\begin{tabular}{|c|c|c|c|c|}
\hline & types of COMPs & non-past form & past form & symbol \\
\hline a. & the [-Q] marker & go & go/gur & that \\
\hline b. & the direct relative marker & $a$ & $a$ & $\mathrm{aL}$ \\
\hline c. & the indirect relative marker & $a$ & $a / a r$ & $\mathrm{aN}$ \\
\hline
\end{tabular}

Let us illustrate the properties of the COMPs by relevant examples. is a declarative sentence, and the embedded clause is headed by the $[-\mathrm{Q}]$ COMP gur 'that.' On the other hand, when the sentence involves wh-interrogative clause formation, as in (6), the embedded COMP must change to the direct relative marker $a L$, and at the same time, another COMP $a L$ must be inserted right after the wh-phrase.
(5)

Creideann Seán gur cheannaigh Máire an carr.
believe John that bought Mary the car
'John believes that Mary bought the car.'

2 The complementizer forms used with irregular verbs in the past tense in Irish, namely, the $[-\mathrm{Q}]$ marker and indirect relative marker $a N$ do not follow the regular usage found with all other verbs. Hence, the regular complementizer forms gur 'that' and the indirect relative form ar are replaced by go 'that' and $a$ 'aN,' respectively when used with the following irregular verbs: $b i$ ' to be' $>>$ go/a raibh; déan 'to do' >> gola ndearna; faigh 'to get' $>$ gola bhfuair; tabhair 'to give' >> gola dtug; tar 'to come' >> gola dtáinig and téigh 'to go' > go/a ndeachaigh. 
(6) Cad é a chreideann tú a cheannaigh Seán t? what aL believe you aL bought John

'What do you believe that John bought?' (movement) (aL, aL, $t$ ) There is another way to form a wh-interrogative clause. Observe example (7).

(7) Cad é a gcreideann tú gur cheannaigh Seán é/*t? what aN believe you that bought John it 'What do you believe that John bought?'

(resumption) (aN, that, RP) In (7), the topmost COMP of the wh-interrogative clause is an indirect relative marker $a$ 'aN,' the COMP of the embedded clause is a $[-\mathrm{Q}]$ COMP gur 'that,' and the embedded clause contains a resumptive pronoun (RP) $e$ 'it,' instead of a gap. Note that (7) becomes ungrammatical, if the resumptive pronoun is replaced by a trace, which suggests that $a N$ must bind a resumptive pronoun.

McCloskey (2002) provides an account of the distribution of the COMPs by proposing (8).

(8) a. C whose specifier is filled by Move is realized as $a L$.

b. C whose specifier is filled by Merge is realized as $a N$.

c. C whose specifier is not filled is realized as go/gur.

McCloskey assumes that the SPEC of $a L$ contains a null operator/null pronoun as a result of movement, that in the SPEC of $a N$, there is a basegenerated operator, and that in the SPEC of go/gur, there is no operator, on the basis of the properties of the mixed chains in wh-interrogative/relative clauses, such as (9).

(9) an carr a raibh súil agam a cheannófá $t$ the car aN was hope at.me aL buy.Cond.2.Sg 'the car I hoped you would buy' (aN, aL, $t)$ In (9), the head of the embedded clause is $a L$, and the head of the higher clause is $a N$. Under the assumption that $a L$ is a result of movement, and $a N$ does not involve movement, the relevant structure of (9) will look like (10).

(10) the car [CP XP aN [IP ... [CP YP aL [IP ...t...]]]] Since XP, YP, and $t$ are in the same (mixed) chain, one may assume that all these have the same index, as shown in (11).

(11) the car [CP $\mathrm{XP}_{1}$ aN [IP $\ldots$ [CP $\mathrm{YP}_{1}$ aL $\left.\left.\left[\mathrm{IP} \ldots t_{1} \ldots\right]\right]\right]$

Now, because the lower CP has $a L$, some sort of movement should be involved in the clause. Then, McCloskey assumes that some element should have moved to CP SPEC, which he calls a null operator or a null pronoun 
that originated from the position of $t_{1}$. In (11), then, the SPEC of $a L$ has a null operator/pronoun, and McCloskey attempted to generalize this to the other cases. Then, in the higher clause in (11), the head of CP is $a N$, which indicates that no element has moved to that position. Therefore, McCloskey claims that there is a null operator in the SPEC of $a N$, and the content of the null operator is identical to that of the null operator in the SPEC of the lower CP. He then generalizes this to wh-interrogatives as well. Consider example (12).

(12) Cad é a cheannaigh Seán $t$ ? what aL bought John

'What did John buy?'

In (12), the wh-phrase is in the sentence initial position, and one may assume that it is in CP SPEC. However, McCloskey (2002) attempts to generalize the above idea to this case as well, and assumes that there is a null operator/pronoun in CP SPEC, as shown in (13).

(13) what $\left[\mathrm{CP} \mathrm{XP}_{1}\right.$ aL $\left.\left[\mathrm{IP} \ldots t_{1} \ldots\right]\right]$

In this paper, following McCloskey (2002), we assume the structures in (11) and (13) for relative clauses and wh-interrogatives, respectively.

\section{Irish Data}

Having outlined the particular background, let us consider Irish embedded topicalization. In the following examples, the topic phrase $\mathrm{X}$ in the embedded topicalization construction is intended to have the connotation of 'as for X.' First, the examples in (14)-(16) show that embedded topicalization must involve resumption, not movement, and that the target is CP SPEC.

(14) Creideann siad gur tharraing Seán [an pictiúr de Mháire]. believe they that drew/took John the picture of Mary

'They believe that John drew/took the picture of Mary.'

(15) Creideann siad [an pictiúr de Mháire $]_{1}$ gur tharraing Seán believe they the picture of Mary that drew/took John $\dot{e}_{1} / * t_{1}$.

it

'They believe that John drew/took the picture of Mary.'

(16) *Creideann siad gur [an pictiúr de Mháire $]_{1}$ tharraing Seán é ${ }_{1}$. believe they that the picture of Mary drew/took John it 'They believe that John drew/took the picture of Mary.'

In (16), the topic is between the COMP gur 'that' and the predicate tharraing 'drew/took,' which is not permitted. 
Second, the examples in (17)-(20) show that a [+Q] COMP may host a topic.

(17) Níl a fhios agam ar tharraing Seán [an pictiúr Neg.be the knowledge with.me Q drew/took John the picture de Mháire].

of Mary

'I don't know whether John drew/took the picture of Mary.'

(18) Níl a fhios agam [an pictiúr de Mháire $]_{1}$ ar

Neg.be the knowledge with.me the picture of Mary Q tharraing Seán é 1 .

drew/took John it

'I don't know whether John drew/took the picture of Mary.'

(19) Níl a fhios agam cé a tharraing $t_{2}$ [an

Neg.be the knowledge with.me who aL drew/took the pictiúr de Mháire].

picture of Mary

'I don't know who drew/took the picture of Mary.'

(20) Níl a fhios agam [an pictiúr de Mháire $]_{1}$ cé ${ }_{2}$

Neg.be the knowledge with.me the picture of Mary who

a tharraing $t_{2}$ é $_{1}$.

aL drew/took it

'I don't know who drew/took the picture of Mary.'

Third, the examples in (21) and (22) show that a resumptive pronoun is possible in the subject position in the embedded topicalization construction.

(21) Níl a fhios agam cad é ${ }_{2}$ a cheannaigh [an

Neg.be the knowledge with.me what aL bought the

fear a [tharraing an pictiúr de Mháire]] $t_{2}$.

man aL drew/took the picture of Mary

'I don't know what the man who drew/took the picture of Mary bought.'

(22) Níl a fhios agam [an fear a [tharraing an

Neg.be the knowledge with.me the man aL drew/took the pictiúr de Mháire] $]_{1}$ cad é a cheannaigh sé $t_{2}$.

picture of Mary what aL bought he

'I don't know what the man who drew/took the picture of Mary bought.'

Fourth, and finally, the examples in (23)-(28) show that embedded topicalization in Irish is permissible in non-genuine complement clauses. (23) and (24) show that embedded topicalization is possible in complement 
clauses of factive verbs such as is trua le 'regret.'

(23) Is trua le Seán gur tharraing sé [an pictiúr de Cop regret with John that drew/took he the picture of Mháire].

Mary

'John regrets that he drew/took the picture of Mary.'

(24) Is trua le Seán [an pictiúr de Mháire] ${ }_{1}$ gur tharraing Cop regret with John the picture of Mary that drew/took sé é . $_{1}$ he it

'John regrets that he drew/took the picture of Mary.'

(25) and (26) demonstrate that embedded topicalization is also possible in noun-complement clauses in Irish.

(25) Creideann siad an ráfla gur tharraing Seán [an pictiúr de believe they the rumor that drew/took John the picture of Mháire].

Mary

'They believe the rumor that John drew/took the picture of Mary.'

(26) Creideann siad an ráfla $[\text { an pictiúr de } \text { Mháire }]_{1}$ gur believe they the rumor the picture of Mary that tharraing Seán é 1 . drew/took John it

'They believe the rumor that John drew/took the picture of Mary.'

(27) and (28) show that embedded topicalization is also allowed in adjunct clauses.

(27) Sular cheannaigh Máire [an carr sin], cheannaigh Seán before bought Máire the car that bought John é féin carr. himself car 'Before Mary bought that car, John himself bought a car.'

(28) $\left[\begin{array}{lll}\text { An } & \text { carr } & \sin \end{array}\right]_{1}$ sular cheannaigh Máire $e_{1}$, cheannaigh Seán the car that before bought Mary it bought John é féin carr. himself car

'Before Mary bought that car, John himself bought a car.'

These examples indicate that embedded topicalization in Irish is permissible in non-genuine complement clauses. 


\section{Discussion}

Let us now consider what the above data suggest for the theory of (Irish) syntax. First, McCloskey (1996) argues, based on the distribution of (sentential) adverbs, that Irish does not have I-to-C movement, but rather that the surface position of $\mathrm{C}$ is $\mathrm{I}$, which is a result of C-to-I lowering, and the verb only moves up to I, not to $\mathrm{C}$, in Irish. He defends these claims by adopting Chomsky's (1986: 6) Prohibition on Adjunction defined in (29).

(29) Adjunction to a phrase s-selected by a lexical head is ungrammatical.

Given (29), the example in (30), which is grammatical, would be incorrectly ruled out, as the adverb an chéad Nollaig eile 'next Christmas' seems to be adjoined to the clause s-selected by the lexical head deiridis 'they.used. to.say.'

(30) Deiridís an chéad Nollaig eile go dtiocfadh they.used.to.say the first Christmas other that would.come sé aníos.

he up

'They used to say that next Christmas he would come up.'

(McCloskey (1996: 59, ex. 30) slightly edited) Therefore, he concludes that the adverb is not adjoined to the embedded clause, but the COMP is lowered to the V-I complex.

Furthermore, McCloskey (1996) presents the data in (31)-(33), which involve adjunction of adverbs to wh-interrogative clauses, to defend his claims.

(31) *Ní bhfuair siad amach ariamh [an bhliain sin] cé a bhí Neg found they out ever that-year who aL was ag goid a gcuid móna.

steal.Prog their turf

'They never found out who was stealing their turf that year.'

(McCloskey (1996: 65, ex. 45))

(32) *Níor thuig mé [roimh an Nollaig] cé chomh

Neg.Past understand I before Christmas how

gnóitheach is a bheadh siad

busy as aL be.Cond they

'I didn't realize how busy they would be before Christmas.'

(McCloskey (1996: 65, ex. 46)) 
(33) *Cha bhfuair sé amach ariamh [nuair a moladh $\mathrm{Neg}$ found he out ever when aL recommend.Impers don phost sin é] cé a chuir ina choinne. for.the job that him who aL put against.him 'He never found out who opposed him when he was recommended for that job.'

(McCloskey (1996: 65, ex. 47)) According to him, (31)-(33) are ungrammatical. This is predictable under (29), because due to the existence of the wh-phrase in the wh-interrogative clause in each sentence, the adverb in each case should be adjoined to CP.

However, the fact is that at least (33) is grammatical with the interpretation in which the adverb modifies the embedded clause. Furthermore, we found that the examples in (34)-(36) are grammatical with the interpretation in which the adverbs modify the embedded clauses.

Níl a fhios agam i rith na hoíche cé a
Neg.be the knowledge with.me during the night.Gen who aL
chuala tormán.
heard noise
'I don't know who heard a noise during the night.'

Níl a fhios agam i rith na hoíche cén

Neg.be the knowledge with.me during the night.Gen what.the tormán a chuala mé.

noise aL heard I

'I don't know what noise I heard during the night.'

(36) Níl a fhios agam i rith na hoíche cá

Neg.be the knowledge with.me during the night.Gen what

háit ar chuala mé tormán

place aN heard I noise

'I don't know where I heard a noise during the night.'

In (34)-(36), the adverbial phrase $i$ rith na hoiche 'during the night' is placed before the wh-interrogative clauses, yet the sentences are grammatical with the adverb being interpreted as modifying the embedded clauses. This indicates (i) that under the assumption that the $[+\mathrm{Q}]$ COMPs $a L$ and $a N$ are in C and the wh-phrases are higher than CP SPC in Irish, the topic is also higher than CP SPEC, and (ii) that no C-to-I lowering has taken place in the examples with embedded topicalization. Furthermore, as already shown in (20), not only adjuncts, but also arguments can undergo embedded topicalization, targeting CP. Based on the examples in (34)-(36) and (20), we conclude that no C-to-I lowering takes place in Irish, contrary to McCloskey's (1996) claim. 
Let us then consider the examples in (31) and (32), and examine what factor is involved in the ungrammaticality of the examples. Just like McCloskey (1996), we find (31) and (32) ungrammatical. This is actually due to the fact that the adverbs in (31) and (32) an bhliain sin 'that year' and roimh an Nollaig 'before Christmas' perfectly fit the matrix predicates ni bhfuair 'Neg found' and nior thuig 'Neg.Past understand,' respectively, and most naturally modify them in those positions. Once this kind of close connection is established between the matrix predicate and the adverb, it is quite hard for native speakers of Irish to interpret the sentence in such a way that the adverb is actually associated with the embedded predicate. Therefore, some sort of frozen effect is involved in such a case. On the other hand, in (33), the adverb is sentential, and it is relatively easy for native speakers of Irish to associate the sentential adverb with the embedded predicate.

The following data, which use a simple adverb which is unambiguously associated with an event in the future, confirm the point at issue. In (37), the adverb amárach 'tomorrow' is in the embedded clause, and modifies only the predicate in the embedded clause.

(37) Níl a fhios agam cé a bheas ag obair san

Neg its knowledge at.me who aL be.Fut at work in.the oifig amárach

office tomorrow

'I wonder who will be working in the office tomorrow.'

When it undergoes embedded topicalization, as in (38), it can only modify the embedded predicate, and the sentence is perfectly acceptable.

(38) Níl a fhios agam amárach cé a bheas ag obair

Neg its knowledge at.me tomorrow who aL be.Fut at work san oifig.

in.the office

'I wonder who will be working in the office tomorrow.'

Therefore, as long as some sort of frozen effect is circumvented, embedded topicalization of an adverb across a wh-interrogative clause is perfectly acceptable.

Since the SPEC of $a$ ' $a \mathrm{~L}$ ' is filled with the null operator of the wh-phrase in (38) and other related examples, no matter whether lowering of C, namely, $a$ 'aL,' to the V-T complex takes place, the adverb is not within the projection of $\mathrm{V}+\mathrm{T}$. Rather, it is in the outer SPEC of $a$ 'aL.' Of course, one cannot exclude the possibility that C-to-I lowering still takes place. However, this kind of lowering has no syntactic effect in embedded topicaliza- 
tion. If this is the case, the minimalist guidelines will prevent such an unnecessary operation (lowering) from taking place.

Second, the example in (22) shows that a resumptive pronoun may appear in the highest subject position. McCloskey (1979) originally claims the Highest Subject Restriction in (39).

(39) The Highest Subject Restriction (HSR) (cited from McCloskey (2002: 201) with slight editing)

In languages which have a fully grammaticized resumptive strategy, the only position from which resumptive pronouns are excluded is the highest subject position within the relative clause.

Note that Ó Baoill and Maki (2012) show that the HSR applies to subjects of relative clauses and wh-interrogatives in a parallel fashion. The relevant data are cited below from Ó Baoill and Maki (2012). The examples in (40) and (41) involve relative clause formation, and those in (42) and (43) wh-interrogative formation. The examples in (40) and (42) involve extraction from the object position/resumption in the subject position, and those in (41) and (43) involve extraction from the subject position/resumption in the subject position. The crucial data are (41b) and (43b), which have a resumptive pronoun in the highest subject position, and are ungrammatical.

a. an leabhar ${ }_{1}$ a léigh Seán $t_{1}$

the book aL read John

'the book that John read' (movement)

b. an leabhar $r_{1}$ ar léigh Seán $e_{1}$

the book aN read John it

'the book that John read' (resumption)

(41) a. an fear ${ }_{1}$ a bhí $t_{1}$ breoite

the man aL was ill

'the man who was ill' (movement)

b. *an fear f $_{1}$ a raibh $s e_{1}$ breoite

the man aN was he ill

'the man who was ill' (resumption)

(42) a. Cad é $e_{1}$ a léigh Seán $t_{1}$ ?

what aL read John

'What did John read?' (movement)

b. Cad é $e_{1}$ ar léigh Seán $e_{1}$ ?

what aN read John it

'What did John read?' (resumption) 
(43) a. Cé $e_{1}$ a léigh $t_{1}$ an leabhar seo? who aL read the book this

'Who read this book?' (movement)

b. ${ }^{*} \mathrm{Cé}_{1}$ ar léigh sé an leabhar seo? who aN read he the book this 'Who read this book?' (resumption)

Then, the example in (22) indicates that the HSR is cancelled by a phrase in the topic position, and the generalization on the HSR in (39) does not always hold.

Let us now consider what factor is actually behind the cancellation of the HSR. In the following discussion, we will follow the possible account provided by Ó Baoill and Maki (2012). Ó Baoill and Maki (2012) first provide examples in (44) and (45), and claim that the HSR is cancelled by an additional phrase, such as an adverb.

(44) *Cé ${ }_{1}$ ar imigh $s e_{1}$ ?

who aN left he

'Who left?'

(45) Cé $e_{1}$ ar imigh sé $e_{1}$ trí lá ó shin? who aN left he three days ago

'Who left three days ago?'

They then provide the examples in (46) and (47), which show that the HSR is cancelled not only by an adverb, but also by a coordinate clause.

(46) $* \mathrm{Cé}_{1}$ a raibh $s e_{1}$ breoite?

who aN was he ill

'Who was ill?'

(47) Cé 1 a raibh sé $e_{1}$ breoite agus ag fáil bháis? who aN was he ill and at getting death 'Who was ill and dying?'

Based on these data, they propose (48).

(48) The highest subject is saved by an adverb or a coordinate structure.

At first sight, (48) does not seem to be a true generalization, and the question arises as to what properties an adverb and a coordinate structure share. Ó Baoill and Maki (2012) revise (48), following Higginbotham's (1985) idea that adjuncts involve coordination. Following Davidsonian event semantics, Higginbotham (1985) claims that the example in (49) is given the semantic representation in (50).

(49) John walks slowly.

(50) $\exists e$ [Walk (John, e) \& Slow (e)] 
(50) indicates that there is an event such that it is a walking by John and it is slow (for a walk). If this is true, the structure with an adverb in (45) has a coordinate structure in its semantic representation, just like the structure with a coordinate clause in (47). Then, (48) is further generalized to (51), and one may say that the HSR is cancelled by the addition of a coordinate clause to the HSR structure.

(51) The highest subject is saved by a coordinate structure.

This makes sense, because when a resumptive pronoun in the subject position is in a conjunct of a coordinate structure, it is within a larger constituent, and thus, does not count as the highest resumptive pronoun in the subject position.

In this paper, we essentially adopt this view for the cancellation of the HSR for examples with embedded topicalization. In examples such as (22), reproduced as (52), the resumptive pronoun sé 'he' is in the highest subject position, yet the sentence is perfectly grammatical.

(52) Níl a fhios agam [an fear a [tharraing an

Neg.be the knowledge with.me the man aL drew/took the pictiúr de Mháire] $]_{1}$ cad é $e_{2}$ a cheannaigh sé $t_{2}$. picture of Mary what aL bought he 'I don't know what the man who drew/took the picture of Mary bought.'

(52) involves embedded topicalization, and the subject [an fear a [tharraing an pictiúr de Mháire]] 'the man $\mathrm{aL}$ drew/took the picture of Mary' functions as the topic of the embedded clause. Then, in a sense, the embedded clause consists of two parts, namely, a topic and its comment, as in (53).

(53) a. a topic X, and

b. a comment on $\mathrm{X}$

If this is true, the embedded structure with a topic in (52) has a coordinate structure in its semantic representation, so that the resumptive pronoun in the subject position in (52) is in a conjunct of a coordinate structure, and thus, does not count as the highest resumptive pronoun in the subject position.

Third, all the examples shown above indicate that [-Q] COMPs, whether they are selected by the higher verbs or not (complements or non-complements of the verbs), and [+Q] COMPs, may bear a [+TOPIC] feature in Irish. On the other hand, in English, for example, C cannot bear a [+TOPIC] feature, as shown in (54). 
(54) a. *John believes this book that Mary read.

b. *John wonders this book whether Mary read.

c. *John regrets this book that Mary read.

d. *John believes the rumor this book that Mary read.

e. *This book before Mary read, John had already read it.

The contrast between Irish and English thus suggests that the relevant head for embedded topicalization is COMP in Irish, and it is INFL in English. Note that the parallel behavior in English and Japanese embedded topicalization suggests that the relevant head for embedded topicalization is also INFL in Japanese. This indicates that the head positions in charge of embedded topicalization are parameterized among languages. If this is true, no independent head for a topic phrase need be assumed unless it is independently needed in the language.

Fourth, the difference in the head positions in charge of embedded topicalization lies in the relationship between the COMP and the INFL in the given languages. Irish has overt COMP-Predicate (verb+INFL) agreement, as shown in (55).
a. Síleann Seán go gceannófá carr. think John COMP buy.Cond.2.Sg car
'John thinks that you would buy a car.'
b. Síleann Seán gur cheannaigh tú carr. think John COMP.Past bought you car 'John thinks that you bought a car.'

In (55a), the embedded predicate (verb+INFL) is in the conditional form, and the COMP is represented as go, while in (55b), the embedded predicate is in the past tense form, and the COMP is represented as gur. The same agreement patterns appear with embedded topicalization as well, as shown in (56).

(56) a. Síleann Seán [an carr mór sin $]_{1}$ go gceannófá é ${ }_{1}$. think John the car big that COMP buy.Cond.2.Sg it 'John thinks that you would buy that big car.'

b. Síleann Seán [an carr mór sin $]_{1}$ gur cheannaigh think John the car big that COMP.Past bought tú é .

you it

'John thinks that you bought that big car.'

This indicates that there is a visible agreement relationship between the COMP and the predicate (verb+INFL) in Irish. Then, once the head in charge of embedded topicalization is placed between COMP and INFL, this 
morphological agreement relationship cannot hold, so that no embedded topicalization is allowed.

On the other hand, if COMP can do the work for embedded topicalization, the agreement is successfully established. In English and Japanese, being non-verb initial languages, however, there is no such visible agreement between COMP and INFL which would be blocked when COMP is in charge of embedded topicalization.

\section{One Remaining Question}

Before closing, we will address one remaining question arising from a comparative study of embedded topicalization in Irish, English, and Japanese. Maki et al. (1999) claim, based on the parallel behavior of embedded topicalization in English and Japanese, that the phenomenon in these two languages receives a uniform account, and propose that INFL licenses an embedded topic in its SPEC, and INFL itself needs to be licensed by COMP by adjoining to it at LF. Therefore, the contrast between (2a) and (2e) in English, reproduced as (57a) and (57b), and the contrast between (3a) and (3e) in Japanese, reproduced as (58a) and (58b), are explained in the following way.

(57) a. John believes that this book, Mary read.

b. *Before this book, Mary read, John had already read it.
a. John-wa [kono hon-wa/-o Mary-ga yonda to] John-Top this book-Top/-Acc Mary-Nom read COMP shinjiteiru.
believe
'John believes that this book, Mary read.'

b. [Kono hon-*wa/-o Mary-ga yomu maeni], John-wa this book-Top/-Acc Mary-Nom read before John-Top sudeni yondeita.

already had read

'Before this book, Mary read, John had already read it.' $(=(3 a)$ and $(3 e))$

First, in all of these examples, the topics are licensed in IP SPEC, and then, INFL moves to COMP at LF. However, the $b$-examples in (57) and (58) involve adjunction of INFL to the head of adjunct clauses, which is prohibited by Takahashi's (1994) ban against adjunction to non-L-marked phrases, namely, adjuncts and derived subjects. 
In Irish, embedded topicalization is possible in complement clauses and adjunct clauses, as shown in (15) and (28), reproduced as (59) and (60), respectively.

(59) Creideann siad [an pictiúr de Mháire $]_{1}$ gur tharraing Seán believe they the picture of Mary that drew/took John $\dot{e}_{1} / * t_{1}$. it

'They believe that John drew/took the picture of Mary.' $\quad(=(15))$

(60) $\left[\begin{array}{lll}\text { An } & \text { carr } & \sin \end{array}\right]_{1}$ sular cheannaigh Máire é $e_{1}$, cheannaigh Seán the car that before bought Mary it bought John é féin carr. himself car

'Before Mary bought that car, John himself bought a car.'

In (59) and (60), the topic is in CP SPEC in each case, and these examples are grammatical. The question that immediately arises is why (60) is perfectly grammatical, in spite of the fact that the topic is in the SPEC of the clause which is an adjunct, which indicates that the merge operation necessarily involves adjunction to an adjunct.

However, there is a clear difference between embedded topicalization in Irish and embedded topicalization in English, for example. Lasnik and Saito (1992) point out that English embedded topicalization does not allow the resumptive pronoun strategy, as shown in the contrast between (61a) and (61b).

(61) a. I believe that this book, you should read $t$.

(Lasnik and Saito (1992: 76, ex. 37a))

b. *I believe that this book, you should read it.

(Lasnik and Saito (1992: 77, ex. 42))

On the other hand, embedded topicalization in Irish must leave a resumptive pronoun. Therefore, a topic in an embedded clause in Irish is merged/ adjoined to $\mathrm{C}^{\prime} / \mathrm{CP}$ by external merge, while a topic in an embedded clause in English is merged/adjoined to IP by internal merge. Furthermore, licensing of INFL in the embedded topicalization construction in English involves movement/adjunction to COMP, again, by internal merge. On the other hand, in embedded topicalization in Irish, COMP itself does not move further in order to be licensed, as it can license the topic phrase in its SPEC if it has to.

Thus, the above facts seem to suggest that the ban against adjunction to adjuncts distinguishes internal merge from external merge, and it only 
disallows adjunction to adjuncts by way of internal merge. If this is correct, then it follows that embedded topicalization in Irish is allowed within non-L-marked phrases, and the contrast between Irish on the one hand, and English and Japanese on the other, is correctly captured. Therefore, the question we addressed in this section turned out to suggest that the ban against adjunction to adjuncts only disallows adjunction to adjuncts by way of internal merge.

Furthermore, as one of the referees correctly points out, our analysis, in which the topicalized phrase in Irish embedded topicalization occupies the (outer) SPEC of C, and is introduced there by means of Merge, seems to contradict McCloskey's generalization of the distribution of Cs in (8), because the form of $\mathrm{C}$ should be $a N$, rather than gur. If McCloskey is correct, what moves/is inserted in wh-interrogatives and relative clauses is a null pronoun or a null operator. On the other hand, in embedded topicalization, what is actually inserted is not a null pronoun or a null operator, but a phrase with phonetic content in McCloskey's analysis and our analysis. We thus claim that this difference is reflected in the form of COMP. Therefore, the contradiction between our analysis and McCloskey's COMP system has turned out to suggest a new property of COMP in Irish, where merger of a phrase with phonetic content does not change the form of COMP in Irish.

\section{Conclusion}

In this paper, we investigated the properties of Irish embedded topicalization in detail, and based on the findings, we argued (i) that lowering of COMP to INFL does not take place in Irish, contrary to McCloskey's (1996) claim, (ii) that the Highest Subject Restriction (HSR) does not apply to resumptive pronouns involved in Irish embedded topicalization, (iii) that both $[-\mathrm{Q}]$ and $[+\mathrm{Q}]$ COMPs may bear a [+TOPIC] feature in Irish, and the head positions in charge of embedded topicalization are parameterized among languages, (iv) that the difference in the head positions in charge of embedded topicalization lies in the relationship between the COMP and the INFL, and (v) that the ban against adjunction to adjuncts only disallows adjunction to adjuncts by way of internal merge. 


\title{
REFERENCES
}

Authier, Marc (1992) "Iterated CPs and Embedded Topicalization," Linguistic Inquiry 23, 329-336.

Chomsky, Noam (1986) Barriers, MIT Press, Cambridge, MA.

Chung, Sandra and James McCloskey (1987) "Government, Barriers, and Small Clauses in Modern Irish," Linguistic Inquiry 18, 173-237.

Grimshaw, Jane (1990) Argument Structures, MIT Press, Cambridge, MA.

Higginbotham, James (1985) “On Semantics," Linguistic Inquiry 16, 547-594.

Lasnik, Howard and Mamoru Saito (1992) Move $\alpha$ : Conditions on Its Application and Output, MIT Press, Cambridge, MA.

Maki, Hideki, Lizanne Kaiser and Masao Ochi (1999) "Embedded Topicalization in English and Japanese," Lingua 109, 1-14.

McCloskey, James (1979) Transformational Syntax and Model Theoretic Semantics: A Case Study in Modern Irish, Reidel, Dordrecht.

McCloskey, James (1996) "On the Scope of Verb Movement in Irish," Natural Language and Linguistic Theory 14, 47-104.

McCloskey, James (2002) "Resumption, Successive Cyclicity, and the Locality of Operations," Derivation and Explanation in the Minimalist Program, ed. by Samuel David Epstein and T. Daniel Seely, 184-226, Blackwell, Malden, MA.

Ó Baoill, Dónall P. and Hideki Maki (2012) "On the Highest Subject Restriction in Modern Irish," English Linguistics 29, 357-368.

Stowell, Tim (1981) Origins of Phrase Structure, Doctoral dissertation, MIT.

Takahashi, Daiko (1994) Minimality of Movement, Doctoral dissertation, University of Connecticut.

Watanabe, Akira (1993) "Larsonian CP Recursion, Factive Complements, and Selection," NELS 23, 523-537.

[received July 18, 2013, revised and accepted January 16, 2014]

\author{
(Hideki Maki) \\ Faculty of Regional Studies \\ Gifu University \\ 1-1 Yanagido, Gifu 501-1193 \\ e-mail:makijp@gifu-u.ac.jp \\ (Dónall P. Ó Baoill) \\ Faculty of Regional Studies \\ Gifu University \\ 1-1 Yanagido, Gifu 501-1193 \\ e-mail: d.obaoill@queens-belfast.ac.uk
}

